\title{
Roth's The Counterlife and the Negotiation of Reality and Fiction
}

\author{
Pia Masiero \\ Ca' Foscari University of Venice
}

Follow this and additional works at: https://docs.lib.purdue.edu/clcweb

Part of the Reading and Language Commons

Dedicated to the dissemination of scholarly and professional information, Purdue University Press selects, develops, and distributes quality resources in several key subject areas for which its parent university is famous, including business, technology, health, veterinary medicine, and other selected disciplines in the humanities and sciences.

CLCWeb: Comparative Literature and Culture, the peer-reviewed, full-text, and open-access learned journal in the humanities and social sciences, publishes new scholarship following tenets of the discipline of comparative literature and the field of cultural studies designated as "comparative cultural studies." Publications in the journal are indexed in the Annual Bibliography of English Language and Literature (Chadwyck-Healey), the Arts and Humanities Citation Index (Thomson Reuters ISI), the Humanities Index (Wilson), Humanities International Complete (EBSCO), the International Bibliography of the Modern Language Association of America, and Scopus (Elsevier). The journal is affiliated with the Purdue University Press monograph series of Books in Comparative Cultural Studies. Contact: <clcweb@purdue.edu>

\section{Recommended Citation}

Masiero, Pia. "Roth's The Counterlife and the Negotiation of Reality and Fiction." CLCWeb: Comparative Literature and Culture 16.2 (2014): <https://doi.org/10.7771/1481-4374.2413>

This text has been double-blind peer reviewed by $2+1$ experts in the field.

The above text, published by Purdue University Press @Purdue University, has been downloaded 606 times as of $11 /$ $07 / 19$.

This document has been made available through Purdue e-Pubs, a service of the Purdue University Libraries. Please contact epubs@purdue.edu for additional information.

This is an Open Access journal. This means that it uses a funding model that does not charge readers or their institutions for access. Readers may freely read, download, copy, distribute, print, search, or link to the full texts of articles. This journal is covered under the CC BY-NC-ND license. 


\section{PURDUE}

UNIVERSITY PRESS <http://www.thepress.purdue.edu>

\section{CLCWeb: Comparative Literature and Culture}

ISSN 1481-4374 <http://docs.lib.purdue.edu/clcweb> Purdue University Press @Purdue University

CLCWeb: Comparative Literature and Culture, the peer-reviewed, full-text, and open-access learned journal in the humanities and social sciences, publishes new scholarship following tenets of the discipline of comparative literature and the field of cultural studies designated as "comparative cultural studies." In addition to the publication of articles, the journal publishes review articles of scholarly books and publishes research material in its Library Series. Publications in the journal are indexed in the Annual Bibliography of English Language and Literature (Chadwyck-Healey), the Arts and Humanities Citation Index (Thomson Reuters ISI), the Humanities Index (Wilson), Humanities International Complete (EBSCO), the International Bibliography of the Modern Language Association of America, and Scopus (Elsevier). The journal is affiliated with the Purdue University Press monograph series of Books in Comparative Cultural Studies. Contact: <clcweb@purdue.edu>

\begin{tabular}{c} 
Volume 16 Issue 2 (June 2014) Article 13 \\
Pia Masiero, \\
"Roth's The Counterlife and the Negotiation of Reality and Fiction" \\
<http://docs.lib.purdue.edu/clcweb/vol16/iss $2 / 13>$ \\
\hline Contents of CLCWeb: Comparative Literature and Culture 16.2 (2014) \\
Thematic Issue History, Memory, and the Making of Character in Roth's Fiction \\
Ed. Gustavo Sánchez-Canales and Victoria Aarons \\
<http://docs.lib.purdue.edu/clcweb/vol16/iss $2 />$
\end{tabular}

Abstract: In her article "Roth's The Counterlife and the Negotiation of Reality and Fiction" Pia Masiero analyzes some aspects of the readers' negotiations of Phillip Roth's 1986 novel. Masiero shows how Roth in the novel's first chapter "Basel" anatomizes what follows and provides the rules of pertinence which guide the text and the keys to interpret its meaning. Masiero argues that the effects of perspective created by the employment of third-person narration and contra-punctual simultaneous narratives prepare readers to the metafictional choices they encounter in the final chapters of the book. With her analysis, Masiero posits that the novel turns out to be a journey in Nathan Zuckerman's writerly mind and a window on how our own minds work. 


\section{Pia MASIERO}

\section{Roth's The Counterlife and the Negotiation of Reality and Fiction}

Philip Roth's The Counterlife is a puzzling read: presenting alternative and contradictory versions of the events concerning the lives of the Zuckerman brothers, Nathan and Henry, the novel violates a basic (readerly) expectation, namely the presence of a story with a unified (or at least retraceable) plot line. Roth said that "In many ways it's everything that people don't want in a novel ... It isn't that it lacks a beginning, middle and ending; there are too many beginnings, middles and endings ... Because one's original reading is always being challenged and the book progressively undermines its own fictional assumptions, the reader is constantly cannibalizing his own reactions" (Roth qtd. in Milbauer and Watson 252-53). All the readings of Roth's novel I am aware of stress the metafictional tonality of the book, its relishing a postmodern game playing hide and seek with the reader while maintaining a strong hold on mimetic conventions. Roth himself defines the book "as fiction about structure" contrasting it with The Facts: A Novelist's Autobiography which stages, instead, "the structure of a life without the fiction" (Novels 311).

In the article at hand I analyze the reader's negotiation of Roth's self-reflexive fiction and argue that its complexities and their resolution are adumbrated in the first chapter of The Counterlife, "Basel." The beginning, as Edward W. Said argues, "is the first step in the intentional production of meaning" (5). I am interested in illuminating "the first step" so as to unearth the intended meaning the reader is invited to produce (cooperatively). In "Basel" Roth anatomizes what follows, provides the rules of pertinence which guide the text and so doing supplies the road map to reach the final destination, namely, the end of the reading experience successfully. The two most disruptive scenes in the novel which present metaleptic transgressions - Henry's reading what we have been reading and thrashing draft \#2 in chapter four and Maria Zuckerman's threat to leave the book in chapter five as much as the contrapuntal pattern and the various instances of a third person narrating voice, can be read and interpreted along the lines "Basel" presents and authorizes. The Counterlife, not only "scrutinises its own composition" detailing its creation, but "incorporates the tools to interpret it and unlock its meaning in that very scrutiny" (Brauner 65). The interpretative trajectory I present sheds light on a larger issue that plays a central role not only in the novel, but in Roth's macrotext altogether: the relationship between facts and fiction and the possibility of distinguishing between the two passing through a reflection on the notion of the self. As David Brauner suggests, "from the outset The Counterlife draws attention to the subjective nature of its own storytelling processes" (70). The guiding logic of the analysis I propose is "transactive," an explicit exposition of the reader's transaction with the text (see Holland), not so much in terms of idiosyncratic responses - there is one for each reader involved and the task would be impossible and ultimately useless - but in terms of an examination of the inferential processes readers are likely to activate to cope with the nature of the text they are reading in order to come to a satisfactory narrative understanding. I submit that this calls for an investigation of the narratological dynamics which underly the "Basel" chapter and the novel as a whole.

The activation of interpretative trajectories starts from the title of the first chapter - "Basel." Basel, as we come to learn some pages into the chapter, is where Maria, Henry's Swiss lover, comes from and where she wants him to follow her leaving his life as a family man behind. Basel stands for the dream Henry has forced himself not to dream - the dream "to be remade in Europe with a European wife, to become in Basel an unfettered, robust, fully grown-up American expatriate dentist" (13). The opening title refers to a place that may be termed a counter place, that is, a place where Henry could have lived his counterlife, a place symbolizing the ruthlessness of a different life as opposed to the obligation and dutifulness of real life - selfishness as opposed to goodness; Basel does not exist in his biography as the unfettered identity it would have represented does not exist in his lived life. The book, thus, opens with a place that belongs to the diegesis only insofar as it stands for something which is not, something which has not been chosen, something against which reality is inevitably measured (and found faulty) so much so as to mine its very foundations. The cognitive training camp, the (readerly) journey in understanding that sets the coordinates for interpreting the book, begins 
with acknowledging the choice of the title and absorbing its implications. The reader is asked to cope with different layers describing different kinds of reality - one factual, the other imaginative - both enmeshed in the emotional tissue of the characters involved (in living and in imagining) as to seem to be interchangeable. Which of the two is more real, more relevant and pertinent to the characters' lives and to their sense of themselves, is an issue far from being easy to settle. The danger and the vertigo of interchangeability and the undecidability concerning the foundations of selfhood and self-perception are already foreshadowed in what the title of the chapter refers to. Since this is not the only title of the book concerning a place, its intrinsic counter factuality and the relevance of its otherness to the protagonists' awareness of themselves alert readers to the danger of taking at face value the other geographical titles ("Judea" and "Glouchestershire") as well: what seems to be the most factual piece of information - the name of a place - turns out to be problematic, or, to say the least, doublelayered. Once past the title, the reader enters a long stretch of italicized text occupying the first eight pages. We are told about the chain of events spanning a year that brought Henry to opt for surgery and die. The telling is handled by a narrator referring to Henry, clearly the focus of these pages, in the third person. As "Basel" goes a long way in fleshing out the identities of the two Zuckerman brothers, it is mandatory to understand the features of this telling. Henry's inner life, his thoughts and emotions are up front and provide the first ingredients which enable us to fill the territory of this story world. But who provides the ingredients to fill it?

Let us consider this device typical of fictional worlds trying to understand the relevance of this narratological choice: what kind of job may Roth want this third person situation to do in the larger context of the whole book? To answer this question we have to examine how readers process the representation of another's mind mental activity, which is what third person narratives usually do. All in all, when confronted with such a situation, readers may be entering one of three scenarios each presenting a different narrating position: 1 ) a story world presented by an unrepresented (authorial) narrator; 2) a story world evoked by a represented narrator; and 3) a story world emerging from the protagonist's perspective. In all three cases, readers expect from this choice a somewhat less biased slant, a more detached and neutral representation of events. The decision concerning which of the three situations is at work is not an abstract one, but derives from our engagement with the text, our making hypotheses and our refining them while we read on. The first case is textually ruled out by what follows the italicized text, which makes it clear that the three thousand words we have been reading had been written by Nathan after receiving Carol's invitation to think about delivering a eulogy for his brother's funeral. And yet, the scope of the narrator's knowledge could (and may actually) have been taken to signal precisely such an authorial instance. This means, pretty much obviously, that we are led to believe something (narratologically speaking) and then we are told how things really are. Let us keep this in mind. In the second case, we need to postulate the presence of someone in the diegetic universe inhabited by Henry who knew the protagonist so intimately as to be able to report Henry's thoughts and feelings - a witness or a confessor privy to the existentially tragic development of his predicament. The end of the italicized text provides the piece of information that allows us to understand the privileged knowledge of the narrator: "That night, from his study, he again phoned Nathan, his last remaining consolation, and this time found him home. He was barely able to prevent himself from dissolving in tears when he told his brother that he was seriously ill and asked if he could come to see him" (11). And in the third case we have a figural narrative in which we may or may not recognize and distinguish the presence of the narrator depending on his alignment (or "consonance" in Dorrit Cohn's terms) with the focalizing character's worldview. The typically intended effect of this choice concerns the illusion of an unmediated access to the character's mind and to his subjective world. The sentence just quoted may actually be invoked to demonstrate this figural situation.

Once the figural situation is verified all the various possible hypotheses lead us to Nathan Zuckerman: on the one hand, the highly emotional meeting between the two brothers offers the perfect explanation of Nathan's knowledge of his brother's predicament and on the other, Nathan being a professional writer goes a long way in explaining the way in which he plays the part of the (authorial) narrator: after all he is an author. Estranged angrily from his brother after the blow Carnovsky has inflicted to his family, in a highly pressured moment of his life Henry forgets it all and tells Nathan, the author, everything. The text we have been reading is the result of this overflowing: Nathan reports what he has been told referring to his brother in the third person giving his narrative the force of his 
brother's restricted focalization while maintaining his audible authorial presence. The third person who opens the novel represents and symbolizes the filtering at work in the narrative we are reading. Henry comes to us through the lens of Nathan's narration, which, in spite of its restricted focalization, bears the traces of another presence, another perspective. The filtering and the mediation are amplified typographically by the presence of italics which not only, as Brauner suggests, renders "the status of the initial text ... uncertain" (70), but points to a manipulation: a decision taken by someone to signal a difference. What kind of difference the italics announce is spelled out explicitly in the lines which follow: "Needless to say, these were not the three thousand words that Carol had been expecting when she'd phoned the evening before the funeral" (11).

The story these lines begin to weave displays a typographical variation - normal type - and a narratological similarity - a third person narrative. Since we resolved the first narrative situation assuming Nathan to be the ventriloquist assigning Henry center stage role, we wonder instinctively what is going on here. As the clear focus of these pages is Nathan himself, these first lines beg an obvious question: why does Nathan, the narrator, not employ the most obvious first-person pronoun now that he speaks about himself? The pages which make up the rest of the chapter revolve around the same kind of narrative situation we meet in the italicized text: a strictly restricted, figural, perspective, this time focalized on Nathan. The employment of deictics which are clear markers of focalization makes the shift in internal focalization unmistakably clear: "this grossly inappropriate text ... he was now going to have" (12). But if Nathan is the focalizing subject, whose is the narrating voice? Well, Nathan's. The simple trick of turning "Basel" (italicized part excluded) into a first person account demonstrates that here we are facing Nathan's first-person in disguise, a Nathan who, nonetheless, plays his authorial tricks on himself as well, mixing strictly restricted focalization with authorial detachment such as "So the surviving Zuckerman brother passed the long afternoon" (37). The fact that there are no other third persons and other italicized passages in the whole book with the exception of the last section of the "Gloucestershire" chapter amplifies the possible relevance of this choice: from "Judea" on, Nathan wears his own shoes, the writer speaking in his own voice. What are Roth's intentions here? To try and answer this question it is necessary to dwell on the other features of this chapter.

After this double beginning, "Basel" proceeds with paragraphs in normal font size alternating with paragraphs in a smaller font. These latter signal the material that comes from Zuckerman's notebooks. We are told that Nathan reads slowly through all the "dozens of shortish entries about Henry and Maria and Carol" scattered throughout the handwritten pages of his notebooks "before trying to figure out what to say at the funeral" (21). This specification is followed by eight entries which give us a taste of the nature of the material composing the notebooks. The reading of these pages in search for an inspiration for the eulogy (one wonders what he expected to find of appropriate enough for the occasion in this kind of materials), overflows the boundaries of the night spent at his desk and invades the following day. The "Basel" chapter, thus, is built on a double track: the events of the day and the contra-punctual comments provided by other entries, tangibly showing "the sort of words that engaged him" away and beyond what actually happens. We are explicitly told that "he was now going to have a very hard time getting through the day without seeing everything that happened as more, a continuation not of life but of his work or work-to-be" (12). As during the night, in spite of the knowledge of the generic requirements "that ruled these occasions ... there was no stopping," so now, during the day, the writer precisely because he is a writer cannot control easily his transforming what is happening into stories which may seem, at first sight, the overdoing of a feverish imagination, but which are, more relevantly, the way the writer has at his disposal to know and understand. This is made clear by the repetition of the word "more" later on in this passage: "Slavish Wendy's mouth was your taste of reckless fun. Old as the hills, the whole world operates this way ... and yet there must be more, there has to be more! How could a genuinely good kid like you, with your ferocious sense of correctness, wind up in this box for the sake of that mouth? And why didn't I stop you?" (16). The scene at Vincent's in American Pastoral in which Zuckerman looks for evidence of the existence of a substratum in the Swede's life echoes (modals included) the logic underlying this excerpt in The Counterlife and shows how Zuckerman's mind works.

Looked at from the writer's perspective, the relation between what is happening (during the afternoon and by extension during his life as a man) and what he actually sees is said to be "a continuation" in which life supplements his present and future work in what seems to be a mutually feeding 
relation: "the little he knew" (11) sparks an idea he develops into a narratively tenable story which returns to life to interact with it (and be transformed and amplified by it) again. Looked at from the reader's perspective, the situation is definitely more intricate: what we experience in reading the juxtaposed pieces of narrative is the depth and complexity of the task of interpretation. We too, along with Nathan, go about the afternoon experiencing a vertiginous doubleness complicated by the very simple fact that whereas the writer knows what is real, that is to say, what belongs to the unwritten world, we have only the written world to cope with as there exists nothing else for us when we read. The kind of juxtaposition "Basel" presents results in our building for ourselves a hierarchy of factuality and applying automatically a generic script positing a notebook or a journal closer to chronicles and reports than fiction writing. Notebook entries are presented as raw material, which, even if written, is as yet untouched by the writer's fully-fledged authorial manipulation. This is, at least, the fiction we are invited initially to believe in keeping with the many references to Nathan Zuckerman's notebooks and their belonging in a middle ground between life and fiction disseminated in the previous Zuckerman Books (on this, see, e.g., Masiero 91).

The juxtaposed structure of the chapter has two interrelated consequences: it makes Nathan's profession the center of what we are reading at least as much as Henry's situation. We see the writer at work, turning still unmilled material into stories; specifically, what we read concerns how "this profession even fucks up grief" (12). This sentence coming early in the (typographically) normal portion of the chapter presents readers with a tool to read what follows as it describes an attitude on Nathan's part not circumscribable to the events at hand - the adverb "even," in fact, gestures to a typical way to go about things that embraces other emotional situations and, more broadly, life itself. Nathan's profession blurs the boundaries between life and his writing fiction. What we are given is a taste of the actual direction this blurring can take with the notebook entries, on the one hand, and the report of the events of the funeral and the reception that follows functioning as "reality bench marks," on the other. This leads to the second consequence of structuring the "Basel" chapter around this syncopated structure: the fiction of the rawness of notebooks entries introduces the notion of the real into fiction. To be more precise, it thematizes the notion of narrative representation and the (much vexed) notion of the obligation to prior sources it entails and evokes, or, on a more abstract level, the relationship between fabula and sujet (see Walsh). In casting light on the workings of the writer's mind, we are led first to believe there exists raw material (here represented by notebook entries, which look like real notebook entries thanks to the smaller font size) pre-existing narrative representation. The book will set this straight in the first pages of the final chapter of the book - "Christendom" - when we are told that in Nathan's notebooks "that ever-enlarging storage plant for [his] narrative factory, ... there is no clear demarcation dividing actual happenings eventually consigned to the imagination from imaginings that are treated as having actually occurred" (247). Here, however, we are led to believe there exists written (narrative) material that may be taken to be undistorted, pure, objective.

"Basel" prepares the ground for what may be considered an uncomfortable but foundational truth, namely, that there is no way to narrate without distortion of one kind or another. As Richard Walsh puts it: "the isolation of any particular sequence is already the intervention of narrative artifice" (53). Considering the narrative nature of our apprehension of ourselves, the step to consider selfhood as mere impersonation is very brief. Thus, Roth's formal choices go a long way in setting the stage for two of the main themes of the book: the relationship between facts and fictions and the definition of subjectivity. The (italicized) beginning, then, is a "false start" only insofar as it is "a text that is defined in terms of what it fails to substitute for" (Brauner 70). It is the most truthful start for what follows: explorative inventions, imaginative variations donned realistically, which are both existentially possible and narratively tenable. In this respect, the authority of the novel's opening that Debra Shostak deems "undermined" because it "tells a tale" rather than represent "reality transparently" (213) remains intact, as it authorizes graphically and formally the generative power of counterfactuality as a means to understand factuality. The doubling of the beginning and the doubling of the third person pronoun thus represent graphically and formally how the seeds of otherness and difference are contained in any event and in any self. Authorizing does not mean authenticating, obviously: the issue of which version of the various lives is the truthful one remains un-decidable. Once it is clear that Nathan hides behind the third person pronoun, the hierarchy of factuality collapses because both the report of the events of the day and the notebook entries come from the same (inevitably biased) 
source. After all, as a writer, he has "the monopoly of words" (Shostak 194). Readers are, thus, first asked to pursue an interpretation and immerse into its emotional and existential consequences and only after this total and fully realistic immersion are they presented with a new textual trajectory that asks for the same complete immersion (and suspension of disbelief) they had granted the first.

The treasure the "Basel" chapter contains as far as interpretative indications are concerned, however, is hidden in plain sight:

If/then. As the afternoon wore on, he began to feel himself straining more and more after an idea that would release those old notes from their raw factuality and transform them into a puzzle for his imagination to solve. While peeing in the upstairs bathroom, he thought, Suppose on that afternoon she'd secretly come to the house ... No, that's not them, thought Zuckerman, and came down the stairs into the living room ... But then it needn't be "them" - could be me, he thought. Us. What if instead of the brother whose obverse existence mine inferred ... I had been the Zuckerman boy in that agony? What is the real wisdom of that predicament? Could it be simple for anyone? If that is indeed how those drugs incapacitate most of the men who must take them to live, then, there's a bizarre epidemic of impotence in this country whose personal implications nobody's scrutinizing. (38-39)

As in American Pastoral, here too the structuring principle of the chapters that follow is laid bare. In the first installment of the trilogy, Zuckerman tells us that while dancing with Joy he began dreaming "a realistic chronicle" (American Pastoral 85) concerning the Swede giving us a clear generic frame to interpret what follows, here, in The Counterlife, we are told how the writer becomes gradually entranced by an engrossing idea concerning the transformation of the raw factuality of the old notebook entries into a story. This transformation is presented as a puzzle for the writer's imagination to solve. Immediately we are offered a possible solution ushered in by the key term "suppose:" the writer's imagination begins to spawn a narrative and a scene takes shape. Then, the writer stops narrating the scene and evaluates whether it is convincing, whether this solution actually solves the puzzle. No, he is not happy with it, there is something wrong, "that's not them," the dialogue he has imagined is not consonant with the persons Henry and Maria are, the scene does not seem to be sustainable, both in existential and in fictional terms. The writer keeps pondering a solution and an epiphanic insight emerges: "it needn't be 'them' - could be me, he thought. Us." (39). Here we are asked to follow a logic which seems to defy reasonableness: once we change the protagonists and Henry and Maria become Nathan and Maria what remains of the raw factuality the writer had started off with?

Roth said in an interview following the publication of The Facts: A Novelist's Autobiography in 1988 that "You begin with the raw material, the facts ... The butcher, imagination, wastes no time with niceties: it clubs the facts over the head ... slits its throat ... By the time the imagination is finished with a fact, believe me, it bears no resemblance to a fact ... Eventually there is a novel" (Roth qtd. in Weber 220). Eventually, in The Counterlife Roth thematizes (and announces to thematize) the work of the writer's imagination. So what remains after the imagination has done its job here? Macroscopically speaking, as Shostak puts it, "the 'fact' that remains is Nathan's urgent act of imagining other selves, other realities, other others" (198; emphasis in the original). Specifically, what remains concerns "the personal implications" of "the bizarre epidemic of impotence in this country" (The Counterlife 38). The realistic tonality of the chapters which follow stems from this seminal moment: the implication of the predicament of impotence will be "scrutinized" in different personal contexts-included the context of the first-person pronoun: "The novel becomes a series of propositions" (Shostak 198) limited to the existential field the writer desires to probe imaginatively. Even if he refers here generically to "anyone" ("Could it be simple for anyone?"), he sketches specifically the hypothetical proposition concerning himself. The coherence here adumbrated, thus, not only refers broadly to the precincts of the writer's imagination, but, specifically to the personal, pronominally represented by the "I" and the "us." The two words which open this crucial paragraph - "If/then" - sum up this trajectory as a sort of caption. How this idea is so persuasive as to become irresistible is attested by the chapters of the rest of The Counterlife. What we are asked to do is to change our readerly perspective and enter the writer's logic shedding our conventional expectations.

The circumvention of any kind of commitment to one (and just one) plot line and to the continuity of characters is contained intrinsically in this solution to the puzzle which can be taken as the premise for a hypertext-like structure. Typical of such a textual environment is the existence of different narrative trajectories within the same text. In spite of not sharing the privilege granted to hypertext read- 
ers, namely that of choosing different story lines, the reader of The Counterlife experiences the same sense of fragmentation and multi-linearity hypertexts revolve around. Even if readers, in the printed world of the book, access the next chapter in line by default, multi-linearity in The Counterlife can nonetheless be reconstructed retrospectively: "Judea" could be coupled with "Aloft" or alternatively with "Christendom," the first section of "Glouchestershire" could be coupled with "Christendom" or find its resolution in its second and third sections; death creates a non sequitur both for "Basel" and "Gloucherstershire." It could be argued that this is true up to a certain point, but I think that the notion of hyper-textuality may be useful to interpret Roth's book because in The Counterlife as well the different trajectories vie with each other without resolving the issue of pre-eminence and dominion. The rule of pertinence that "Basel" has set does not include the rule of non-contradiction, but that of juxtaposition and perspectival doubleness. Needless to say, readers of The Counterlife have a much harder time than hypertext readers as there is no way around the sequential linearity reading depends upon: this implies that readers are vulnerable to cognitive attacks because they are presented with ever-changing protagonists and contexts and decisions defying predictability and they have, thus, to accept shedding their reading habits: instead of connecting events following the typical cause-effect logic, they are required to be flexible enough as to come up with more than a causal chain and consequently more than a possible plot line.

After the close reading of this seminal paragraph and the analysis of the structure of the chapter, what comes next cannot come as a complete surprise. True, as the majority of the first reviews of American Pastoral has demonstrated, the key to interpret a book may be in plain sight, but it may remain hidden. As in the case of the first installment of the American trilogy, the moment of revelation does not occupy a special position (as would be the beginning or the end of a chapter). The "Basel" chapter closes with such a masterful narrative firework - the actual conversation between Nathan and Carol contra-punctually commented by an alternative conversation Nathan imagines and a final taste of Nathan's notebook entries which settles the matter of how interpreting Carol only apparently - that we are liable to forget the if/then paragraph. This, nonetheless, does not mean the key is not there to be used by attentive readers.

Equipped with the interpretive keys "Basel" provides us, readers are ready to negotiate what they encounter in the following chapters. As already mentioned, the second section of "Gloucherstershire" presents the only other instance of third-person narrative in the book outside "Basel." The singularity of these two occurrences in the story world of The Counterlife invites us to consider them on a par. On a macroscopic level they stage the two sides of textual communication: what happens in the mind of the writer and what happens in the mind of the reader: "Basel" being written and "Basel" being read. Speaking narratologically, it is the same kind of third person we have experienced in "Basel," namely a first person in disguise: while in "Basel" it is Nathan to hide behind the third person pronoun, here it is Henry. We face again what we faced in "Basel:" the dance of the pronouns - from he to you to I and back - conveys the same immersive, only superficially detached account. Here is an example which echoes what we have been reading at the beginning of the novel: "The thing that brought our family apart, thought Henry, is here being enshrined ... Here they all sit ... but none of them, for that 'daring' had to pay a goddam dime. All their pieties about saying the unsayable! Well, you ought to see your old parents down in Florida dealing with their bewilderment ... they paid alright, they lost a son to the unsayable! I lost a brother!" (193). Thought-report signaled by tag verbs such as "he thought" gives way to free indirect discourse which, in turn slides into or explodes into overt first person ushered in with a second-person address. The third-person ventriloquizing mask is shed and the rawness of Henry's bafflement at what he interprets as the core of his brother's "voracious" and "voyeuristic" (191) profession emerges. This rawness is often foregrounded by the employment of deictics signaling internal focalization: "Nathan's eulogist praised just those exploitative aspects of Carnovsky that Henry had never been able to forgive and wanted least to hear about at a time like this" (192). The specification "at a time like this" contributes to define Henry's emotional here and now somehow eternally fixed in not understanding and not accepting his brother's books and, for extension, his life.

In the third section of the same chapter after Nathan's death the conversation between Henry and Nathan's former wife, Laura, presents the same contra-punctual pattern structuring the conversation between Nathan and Carol in the "Basel" chapter. There, the conversation actually taking place is complemented by a counter-conversation in which Nathan imagines a different dialogue supplement- 
ing what he has already begun conjecturing about Carol: a counter-Carol just wearing the mask of the spouse believing in her husband's faithfulness. Here, we both hear what Henry says and listen to his thoughts. This scene confirms how "Basel" may be read as a testing zone. Microscopically, the two exchanges present one of the main ingredients of the novel: the double-layered nature of our lives based on a never-ending interplay of what actually happens and what goes on in our heads be it imaginative or re-collective or tangentially meditative. What is real and what is fictional, after all? What will be remembered about that conversation? Will it be possible to disentangle the two competing trajectories? The question is immediately taken up again under a different guise, namely Henry's reading of Nathan's journals in the apartment of his dead brother: he visits it precisely with the purpose of locating any compromising reference to his adulterous affairs. This is the "nasty job to be done" (207) because, "though [Nathan's] brain cells might have been burned to cinders, there was still this memory bank to worry about" (208). Once he finds what he is looking for, he reads through the pages and finds himself recollecting scenes from the "brief, regressive, adolescent interlude" with Maria, his Swiss-German patient. Henry's reading and recollecting doubles what we have already read in the "Basel" chapter and yet Henry specifies that "it was all more compromising than he'd remembered" (208).

The episode is significant in two respects: first, it stages a retelling of something we have already heard. The effect is that we go through a repetition with a difference that increases our awareness that mere neutral reporting is simply impossible. Here are two excerpts reporting the same anecdote, the first comes from "Basel" straight from Nathan's notebooks, the second from "Glouchestershire": "Played his Mel Tormé record for her - had to dance with her while they had the chance. Glued loin to loin the way he danced in high school with Linda Mandel" (25) and "he remembered dancing with her in his own dark house, dancing like kids to Mel Tormé after having spent all afternoon in bed" (209). The differences may be as negligible as not to qualify as counter stories, but they nonetheless point to the validity of the Heisenberg principle in the realm of telling stories as well: there is no way to report an event that does not influence it, coloring it of the color of the narrating perspective. Second, remembering is measured against Nathan's notebooks entries which are thus, once again, implicitly posited as the real: what Nathan has jotted down in his journals is taken to be a neutral record of what really happened without any imaginative surplus. The entries become the map of Henry's territory and inevitably the real territory recedes and is overwritten by one (among the many) possible narratives Nathan's.

The last two sections of "Gloucestershire" and the final pages of the closing chapter "Christendom" present the most intractable textual materials as they transgress the boundary separating what is diegetic from what is extradiegetic, a border which is expected to be impermeable. The kind of transgressions readers face here are so called "ontological metalepses" as they involve "disorienting transgressions of boundaries that are physically or logically impossible, and hence properly unnatural" (Alber and Bell 167). More precisely, both Henry's reading part of the novel we read and Maria's addressing her author and menacing to leave for good the text she belongs to as a character, are dubbed as ascending metalepses because in both cases "a fictional character or narrator jumps from an embedded story world to a hierarchically higher one" (168). What characterizes this kind of metalepses (as opposed to rhetorical ones) is the inevitable breaking of the mimetic illusion and their metafictional quality. I argue that these disruptive scenes amplify on a more explicitly metafictional level what we read in the initial chapter of the novel. In Patricia Waugh's definition, metafiction "is a term given to fictional writing which self-consciously and systematically draws attention to its status as artifact" (2) and as such it makes a "statement about the creation of that fiction" (6). The contra-punctual structure of "Basel" problematizes the relationship between what is real and what is not by juxtaposing different materials whose factuality is eventually short-circuited. The contamination Nathan experiences is only mildly destabilizing for us, but it nonetheless ushers us into the workings of the writer's mind in which life and fiction coexist simultaneously. While reading that first chapter, we experience the default necessity to distinguish and name fiction against reality taking the "raw factuality" of notebook entries at face value. Maria Zuckerman is not the only one to confuse life and fiction. The mimetic quality of the narration - which is pervasive despite its non-sequential structure - triggers cognitive reactions which demonstrate readers' need to measure fiction against something which is admittedly not fiction, something that we typically call "reality." Against the grain of our cognitively automatic reactions, we 
are invited repeatedly to "suppose" and "imagine" to go along the ride with the writer who does this quintessentially.

Metalepses take the game of imagining to a higher level: here we cannot naturalize and resort to the supposed factuality of notebook entries as the cognitively reassuring way out is not available any longer. These metaleptic scenes complement the reflection on the intradiegetic relationship between narrating voice and perspective with a reflection on the metaleptic relationship between author and character. The destabilizing effect is baffling and unsettling and yet it may trigger an interest in the construction and artificiality of narratives. Nathan Zuckerman returns where he belongs - center stage - as the creator of counterlives, the absolute ruler of his fictional world inviting readers to deconstruct hierarchies and explore the possibility of counter-interpretations. At the end, we come up with a series of certainties: we can neither know what actually happened nor what is actually happening and almost certainly there is always something else that is going on. This may be baffling only up to the point it becomes liberating and playfully exhilarating. The choice is not between objective reality and imaginative reality, but between a perceiving and a reading that acknowledge the complex (mostly in vain) task of distinguishing between the two and a perceiving and a reading that do not show to be aware that "in the brain" "memory is entwined with fantasy" (247) as much as in Zuckerman's notebooks. The very title of the novel - counterlife, not counter story - suggests that creating, perceiving, remembering, and imagining are the material reality and our identities, not just the writer's, are made of. Nothing postmodern in this and perhaps a mimetic move indeed.

\section{Works Cited}

Bell, Alice, and Jan Alber. "Ontological Metalepsis and Unnatural Narratology." Journal of Narrative Theory 42.2 (2012): 166-92.

Brauner, David. Philip Roth. Manchester: Manchester UP, 2007.

Cohn, Dorrit. Transparent Minds: Narrative Modes for Presenting Consciousness in Fiction. Princeton: Princeton UP, 1978.

Holland, Norman N. "Re-covering 'The Purloined Letter': Reading as Personal Transaction." The Reader in the Text: Essays on Audience and Interpretation. Ed. Susan Rubin Suleiman and Inge Crosman Wimmers. Princeton: Princeton UP, 1980. 350-70.

Masiero, Pia. Philip Roth's Zuckerman Books: The Making of a Storyworld. Amherst: Cambria P, 2011.

Milbauer, Asher Z., and Donald Watson. "An Interview with Philip Roth." Conversations with Philip Roth. Ed. George J. Searles. Jackson: UP of Mississippi, 1992. 242-53.

Roth, Philip. American Pastoral. New York: Library of America, 2011.

Roth, Philip. Novels and Other Narratives: 1986-1991. New York: Library of America, 2008.

Roth, Philip. The Counterlife. New York: Library of America, 2008.

Roth, Philip. The Facts: A Novelist's Autobiography. New York: Library of America, 2008.

Said, Edward W. Beginnings: Intention and Method. New York: Columbia UP, 1985.

Shostak, Debra. "'This Obsessive Reinvention of the Real': Speculative Narrative in Philip Roth's The Counterlife." Modern Fiction Studies 37.2 (1991): 197-215.

Walsh, Richard. The Rhetoric of Fictionality: Narrative Theory and the Idea of Fiction. Columbus: Ohio State UP, 2007.

Weber, Katharine. "PW Interviews: Philip Roth." Conversations with Philip Roth. Ed. George J. Searles. Jackson: UP of Mississippi, 1992. 220-25.

Waugh, Patricia. Metafiction: The Theory and Practice of Self-Conscious Fiction. London: Methuen, 1984.

Author's profile: Pia Masiero teaches US-American literature at Ca' Foscari University of Venice. Her interests in scholarship include post-classical narratology and contemporary US-American fiction. In addition to numerous articles, Masiero's book publications include Names across the Color Line: William Faulkner's Short Fiction $1931-1942$ (2012) and Philip Roth's Zuckerman Books: The Making of a Storyworld (2011). E-mail: <masiero@unive.it> 